\title{
Propagation Area of Flashover on Solar Array under Electron Environment Simulating Geosynchronous Orbit
}

\author{
Teppei Okumura Non-member (Japan Aerospace Exploration Agency) \\ Kumi Nitta Member (Japan Aerospace Exploration Agency) \\ Masato Takahashi Non-member (Japan Aerospace Exploration Agency) \\ Kazuhiro Toyoda Member (Kyushu Institute of Technology)
}

Keywords : vacuum arc, spacecraft charging, Solar array, geostationary orbit

\section{Introduction}

The electrostatic discharge on a solar array is triggered by a blow-off discharge attributed to the spacecraft capacitance. The blow-off discharge causes a flashover discharge on the solar array. The energy source of the flashover discharge is the capacitance of the coverglass and the insulation sheet. Because the capacitance of spacecraft is not as great as the capacitance of the coverglass and the insulation sheet, the flashover discharge is the major current source of the electrostatic discharge. Because the electrostatic discharge potentially causes an anomaly in the solar array system, an electrostatic discharge test is required before launch to guarantee the quality of the solar array design. To simulate the flashover current, we need the characteristics of flashover discharge, such as a velocity of flashover plasma and propagation area. In this paper, we discuss the result of the flashover discharge experiment on a large solar array panel in a simulated geostationary orbit plasma environment.

The size of the solar array coupon panel is $2 \mathrm{~m}$ in height and $1.2 \mathrm{~m}$ in width; the area is $2.4 \mathrm{~m}^{2}$. There are 24 solar cell strings. We used two solar array coupons with a $0.06-\mathrm{m}$ gap between the solar array coupons; the total area for the experiment is approximately $5 \mathrm{~m}^{2} .5 \mathrm{~m}^{2}$ is the largest area for the flashover discharge experiment.

The pressure ranges between $5 \times 10^{-5} \mathrm{~Pa}$ and $1 \times 10^{-4} \mathrm{~Pa}$. A thin film aluminum foil is set in front of the electron beam gun to scatter the electrons. Therefore, the current density on the solar array coupon is in the order of $\mu \mathrm{A} / \mathrm{m}^{2}$. The acceleration voltage is set to $9 \mathrm{kV}$. However, the electron energy is approximately $7 \mathrm{keV}$ because the electron loses approximately $2 \mathrm{keV}$ when penetrating the aluminum foil. Because the solar array coupon is biased to $6 \mathrm{kV}$, the electron energy is approximately $1 \mathrm{keV}$ when the electron reaches the surface of solar array coupon.

A 32ch oscilloscope is used to measure the voltage and current waveforms. We connected some current probes to some solar cell strings to measure the flashover current and the neutralization current. In the present research, a surface potentiometer was used to estimate the propagation area of flashover plasma. In our experiment, we investigated the relationship between the charge of the neutralization current and the distance from a string where the discharge occurred.

Figure 1 shows the relationship between the charge of neutralization currents and the distance from the discharge spot of one flashover discharge. This graph shows that the neutralized charge is decreasing as the distance increases. In addition, we have seen same tendency in any discharge. This fact means that the flashover discharge does not neutralize whose solar array panel. In

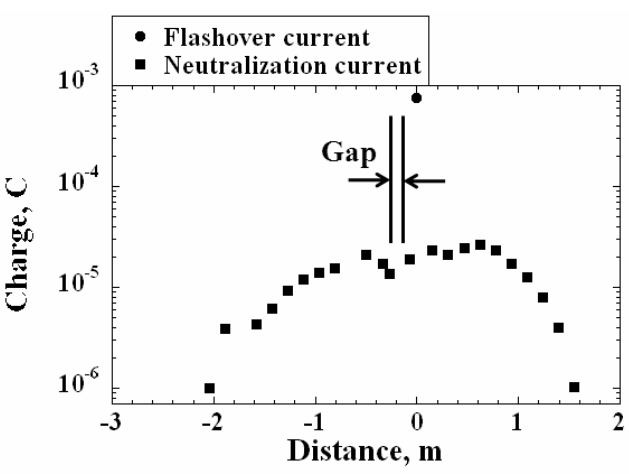

Fig. 1. Relationship between neutralized charge and distance from the discharge spot

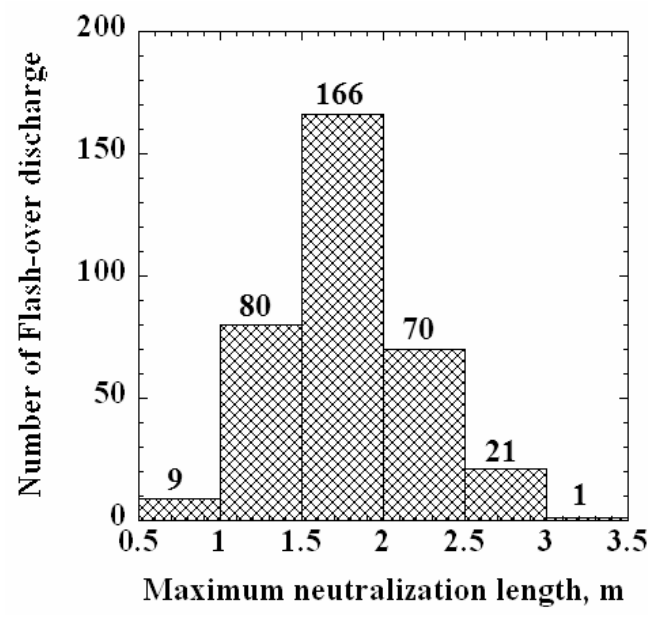

Fig. 2. Distribution of maximum neutralization length

the case of the flashover discharge shown in Fig.1, the maximum propagation length is $2.1 \mathrm{~m}$.

We investigated the relationship between distance from the discharge spot and pulse duration. The result shows that the neutralization area due to flashover discharge increases when the pulse duration is less than $300 \mu$ s. However, the neutralization area does not increase when the pulse duration exceeds $300 \mu \mathrm{s}$. We statistically analyze the neutralization length for the flashover discharge which sustains for more than $300 \mu$ s. Figure 2 shows the distribution of maximum neutralization length. The average neutralization length is $1.76 \mathrm{~m}$. The maximum neutralization length is $3.4 \mathrm{~m}$. 


\section{模擬静止軌道環境下における太陽電池アレイ表面の \\ フラッシオーバ放電の伝搬範囲}

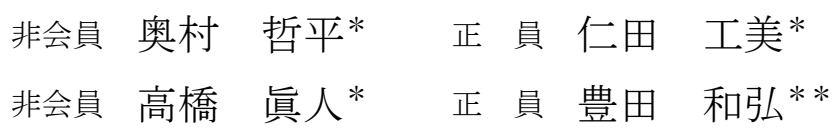

\section{Propagation Area of Flashover on Solar Array under Electron Environment Simulating Geosynchronous Orbit}

Teppei Okumura*, Non-member, Kumi Nitta*, Member, Masato Takahashi*, Non-member, Kazuhiro Toyoda**, Member

Flashover discharge on the solar array is an issue of spacecraft charging, because the discharge potentially causes the catastrophic failure of a satellite. The discharge experiment on solar array has been carried out to investigate the propagation area of flash-over discharge. During the flash-over discharge, neutralization current flows on the solar array strings. The charge of neutralization current was calculated to investigate the relationship between the charge and the distance from the cathode spot. The experiment result in the maximum propagation area of flash-over plasma is $3 \mathrm{~m}$ in simulated geostationary orbit.

キーワード : フラッシオーバ, 衛星帯電, 太陽電池アレイ, 静止軌道

Keywords : flashover, spacecraft charging, solar array, geostationary orbit

\section{1. 研究背景}

宇宙環境では，周辺プラズマとの干渉によって，人工衛 星は帯電する(1)。静止軌道（高度 $36000 \mathrm{~km}$ ）では，サブス トームによって発生する数 $\mathrm{keV}$ 程度の高エネルギー電子が, 人工衛星を帯電させる。この時, 人工衛星の周辺プラズマ に対する電位は一数 $\mathrm{kV}$ 程度となる(1)(2)。一般的な太陽電池 アレイは, Fig.1 に示されるように, カバーガラスや絶縁 フィルムなどの絶縁体, インターコネクタなどの導体が存 在するために, 電気的三重接点が形成される。衛星構体が 一数 $\mathrm{kV}$ に帯電しているので, 数 $\mathrm{keV}$ 程度の高エネルギー電 子は, 絶縁体表面に到達する時, 数百 $\mathrm{eV}$ 程度のエネルギー まで減速する。二次電子放出係数は, 数百 $\mathrm{eV}$ 程度で大きく なるので, 絶縁体表面から発生する電子の個数は, 流入す る電子の個数よりも多くなる(3)。また, 衛星が日照面にある 時は, 光電子放出により絶縁体表面から電子が発生するこ ともある。こうしたことから, 衛星構体が一数 $\mathrm{kV}$ 程度に帯 電すると, 絶縁体表面の電位は衛星構体に対して正になる ことがある。この電位勾配は逆電位勾配と呼ばれている。

\footnotetext{
(独) 宇宙航空研究開発機構，研究開発本部電源グループ 干305-8505 つくば市千現 2-1-1 Japan Aerospace Exploration Agency 2-1-1, Sengen, Tsukuba 305-8505

** 九州工業大学, 宇宙環境技術研究センター 干 804-8550 北九州市戸畑区仙水町 1-1 Kyushu Institute of Technology 1-1, Sensui, Tobata-ku, Kitakyushu 804-8550
}

この電位勾配は, 電気的三重接点で電界強度が増大し, 電 子の電界放出が発生する。電子の電界放出の結果, 太陽電 池アレイ上で放電が発生する可能性がある(1)。

Fig.2 に太陽電池アレイ上での放電の電流経路を示す。電 子の電界放出によって発生した放電により, 人工衛星の電 位は周辺プラズマとほぼ同程度まで回復する。この時流れ る電流の大きさは, 衛星とプラズマとの間の静電容量に依 存する。この放電電流はブローオフ電流と呼ばれる。また, このブローオフ放電が発生した太陽電池では, カバーガラ スなどの表面に蓄積されていた電荷によるフラッシオーバ 放電が発生する。この放電電流をフラッシオーバ電流と呼 ぶ。その際, 放電により発生したプラズマが, 他の列にお ける蓄積電荷を中和しながら進展していくと考えられてい る。宇宙用太陽電池アレイ上の一連の放電現象は一次放電

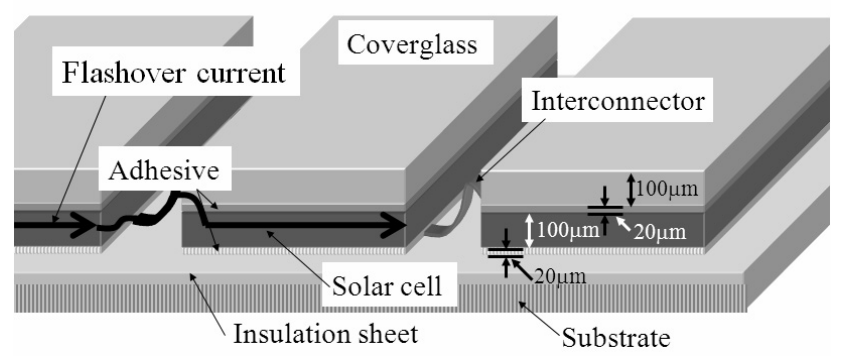

Fig. 1. Cross-sectional view of solar array. 


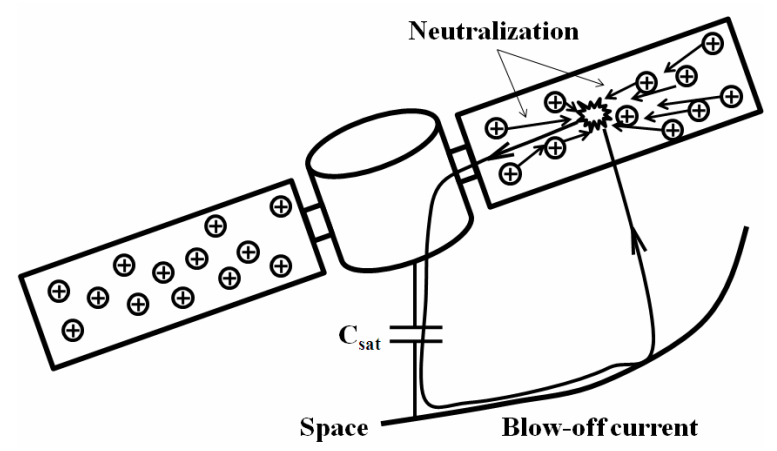

Fig. 2. Current paths of discharge on solar array.

と呼ばれている(4)。

一次放電は, 太陽電池の劣化や, 太陽電池アレイ回路の 短絡原因となる(5)(6)。人工衛星を打ち上げる前に，太陽電池 アレイの放電に対する而性を調べるための帯電放電試験が 行われることがある(7) (9)。こうした帯電放電試験は, 一次 放電電流のエネルギーや電流ピーク值によって結果が異な る可能性が示唆されており ${ }^{(10)}$, 一次放電の正しい理解に基 づいた波形の摸擬が求められている(11)。

一次放電の波形を正確に模擬するためには, 放電プラズ マの伝搬距離や伝搬速度などの特性を知る必要あり, 各国

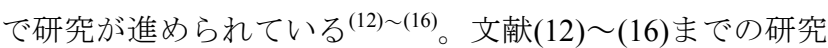
に用いられた太陽電池アレイパネルは最大でも, $1 \mathrm{~m}^{2}$ であ る。実際の太陽電池アレイパネルは遥かに大きいので, $1 \mathrm{~m}^{2}$ 程度の太陽電池アレイパネルを用いて行った実験結果か ら, 放電プラズマの伝播範囲を議論するのは難しい。また, 放電プラズマの伝搬速度の時間変化も調べる必要がある。 そこで, 我々は $5 \mathrm{~m}^{2}$ の太陽電池アレイパネルを用いて放電 プラズマの特性を求めるための実験をおこなった。本論文 では，放電プラズマの伝搬距離に関して議論をおこなう。

\section{2. 実験方法}

〈2・1〉 太陽電池アレイクーポンＦig.3 に示した太陽 電池アレイクーポンパネル（以下，クーポンパネル）は, 実際の人工衛星に用いられる太陽電池アレイと同等のデザ インである。クーポンパネル上には 700 枚程度の化合物太 陽電池が配置されている。インターコネクトにより直列に 接続された 30 から 31 個の太陽電池を 1 列とし, 1 枚のパネ ルにはこれが 24 列，並列に接続される。太陽電池にはカバ 一ガラスが取り付けられており, 表面には反射防止コーテ イングが施されている。真空容器内でのクーポンパネル間 の距離は, 実際の人工衛星の太陽電池アレイを模擬するた めに $60 \mathrm{~mm}$ とした。

〈2·2〉 実験環境 Fig.4 に実験システムの概念図を示 す。真空容器の直径は $2.5 \mathrm{~m}$, 長さは $4 \mathrm{~m}$ である。クライオ ポンプを二基搭載しており, 試験中の容器内の圧力は $1 \times$ $10^{-4} \mathrm{~Pa}$ から $5 \times 10^{-5} \mathrm{~Pa}$ 程度となる。サブストームが発生した 時の, 高エネルギー電子を模擬するために, 真空チャンバ 一には二基の電子銃が取り付けられている。電子ビームの

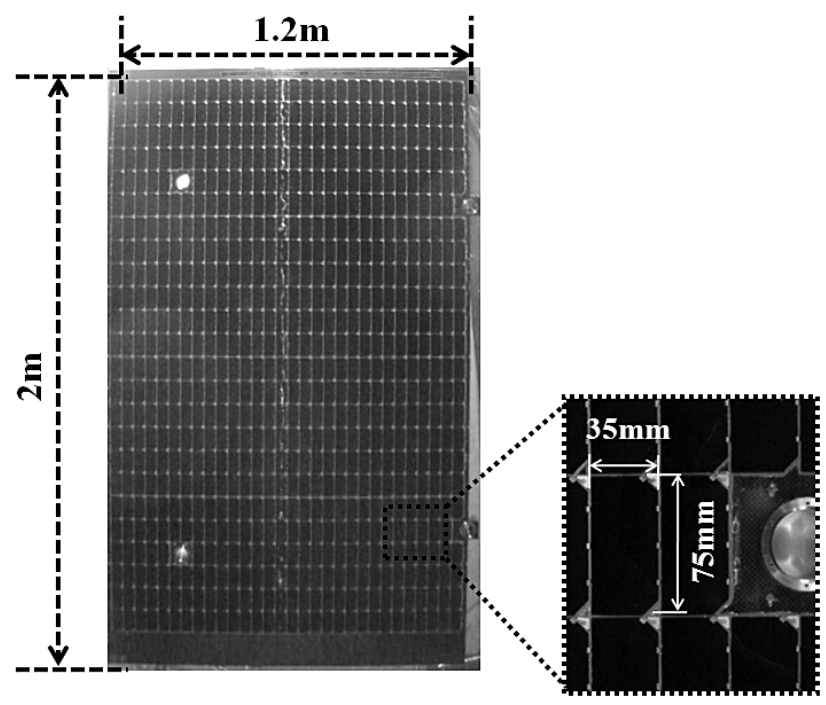

Fig. 3. Solar array coupon.

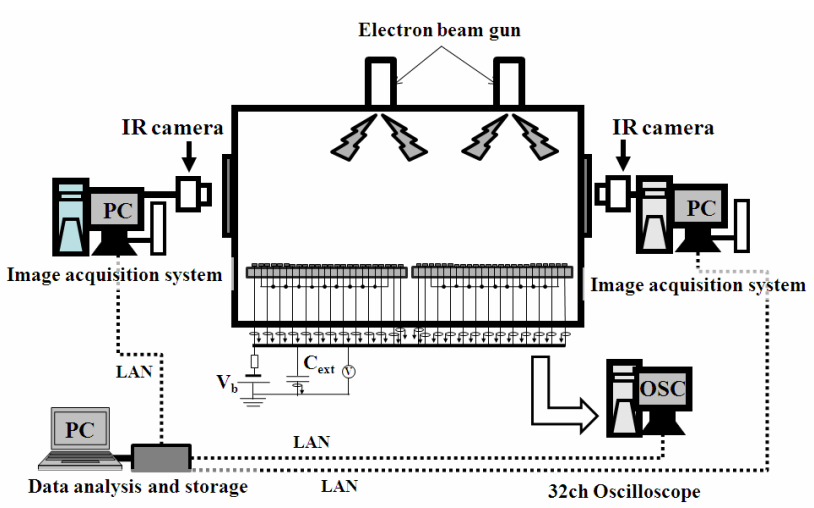

Fig. 4. Experiment system.

加速電圧は $-9 \mathrm{keV}$ とした。電子銃の正面には, 電子ビーム を拡散させるための $0.1 \mu \mathrm{m}$ のアルミ箔が取り付けられてい る。アルミ簿は市販品を使用した。中空の円形銅板でアル ミ箔の両側から挟み, 電子ビーム銃の正面に取り付けた。 電子はアルミ馢を貫通寸る際に $2 \mathrm{keV}$ 程度のエネルギーを 失うので, アルミ箔直後の電子のエネルギーは大きくても $7 \mathrm{keV}$ 程度である。試験中のクーポンパネル表面における電 流密度は $\mu \mathrm{A} / \mathrm{m}^{2}$ 程度である。

〈2.3〉 実験システムと放電試験回路 Fig.5 に放電試 験回路図を示す。ブローオフ放電が発生した太陽電池列に は, フラッシオーバ電流が流れる。これに隣接した太陽電 池列には, フラッシオーバ電流とは逆向きの中和電流が流 れる。太陽電池アレイパネル一枚には, 24 列の太陽電池列 があるので, 合計 48 列の太陽電池列が存在する。 $\mathrm{I}_{\mathrm{st}}$ から $\mathrm{I}_{\mathrm{stn}}$ は, ある太陽電池列を流れる電流波形を測定するための電 流プローブである。電流プローブを取り付けていない太陽 電池列に関しては, 全て結合させて, 電流プローブ $\mathrm{I}_{\mathrm{uni}}$ で測 定した。 $\mathrm{I}_{\mathrm{st} 1}$ から $\mathrm{I}_{\mathrm{stn}}$ の電流プローブは, フラッシオーバ電流 を正しく計測することができる。これに対して， $\mathrm{I}_{\mathrm{uni}}$ の電流 プローブは，フラッシオーバ電流と中和電流が重なり合っ 


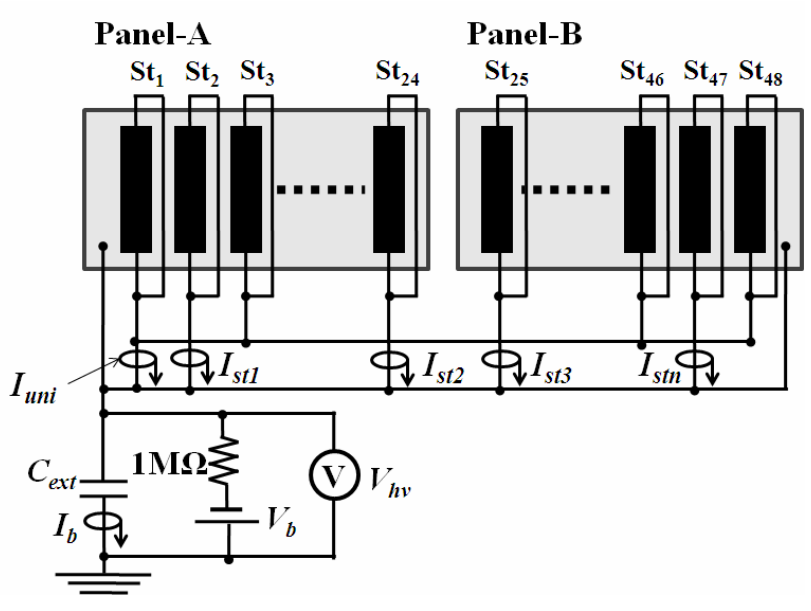

Fig. 5. Test circuit for discharge circuit.

た波形を測定する。32ch オシロスコープはブローオフ，フ ラッシオーバ，中和の電流波形収録と，画像取り込み $\mathrm{PC}$ 人 のトリガ出力をおこなう。微弱な放電発光も検出できるよ うに, 真空容器内部の様子は近赤外カメラを用いて観察し た。画像取り込み PC は, 32ch オシロスコープからのトリガ を受信すると，近赤外カメラの画像を取り込む。

クーポンパネルの表面電位分布は, 表面電位計付き XY ステージを用いて測定した。放電発生時の乘離電圧や電荷 の中和範囲を調べるためには，一定間隔で表面電位を測定 するのが望ましい。しかしながら，本試験ではクーポンパ ネルの表面電位分布測定に要する時間は 5 分である。限ら れた試験期間中に可能な限り大量の放電データを取得する ために，本試験においては，一部の放電について放電発生 後の電位分布を測定した。

$\mathrm{V}_{\mathrm{b}}$ は人工衛星が周辺プラズマに対して持つ電位差を模擬 する。 $\mathrm{V}_{\mathrm{b}}$ は一 $6 \mathrm{kV}$ に設定したので，クーポンパネル表面に は大きくても $1 \mathrm{keV}$ 程度の電子が照射される。二次電子放出 係数は $1 \mathrm{keV}$ 以下のエネルギー領域に最大值を持つので, カ バーガラス内部には逆電位勾配が発生する(1)(3)。 $\mathrm{C}_{\mathrm{ext}}$ は人工 衛星が周辺プラズマに対して持つ静電容量を模擬する。 $\mathrm{C}_{\mathrm{ext}}$ を大きくすると, ブローオフ電流は大きくなり, クーポン パネルに損傷（たとえば，太陽電池や絶縁シートの劣化） を与える恐れがある。よって， $\mathrm{C}_{\mathrm{ext}}$ は可能な限り小さくする 必要がある。しかしながら， $\mathrm{C}_{\mathrm{ext}}$ が小さすぎると発光が小さ くなるので，放電発生個所の検出が困難となる。そこで, 今回の実験では, $\mathrm{C}_{\mathrm{ext}}$ を $240 \mathrm{pF}$ とした。

\section{3. 実験結果}

Fig.6 は電子ビームを 4 分間, 照射した後の電位分布で, 右側パネル上部の表面電位は，他の場所と比較して帯電し ていないが，それ以外の場所では比較的一様に帯電してい ることが分かる。電子ビームの照射時間に対する表面電位 分布を調べた。Fig.7 に示した表面電位と乘離電圧の時間変 化で，各点は表面電位分布の平均值で，エラーバーは標準 偏差を示している。いずれの測定ポイントにおいても標準

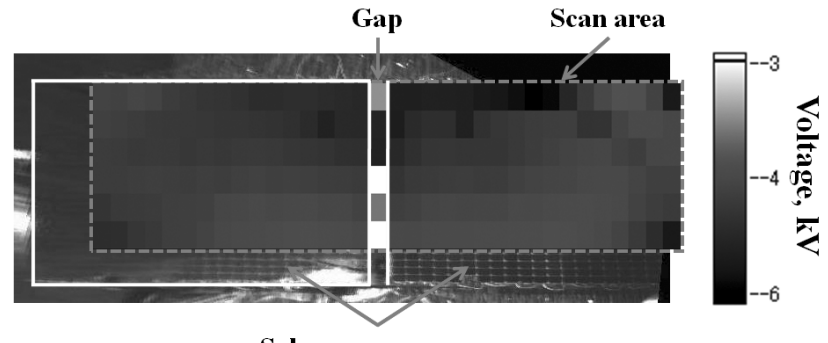

Solar array coupon

Fig. 6. Surface potential profile after 4 minutes electron beam irradiation.

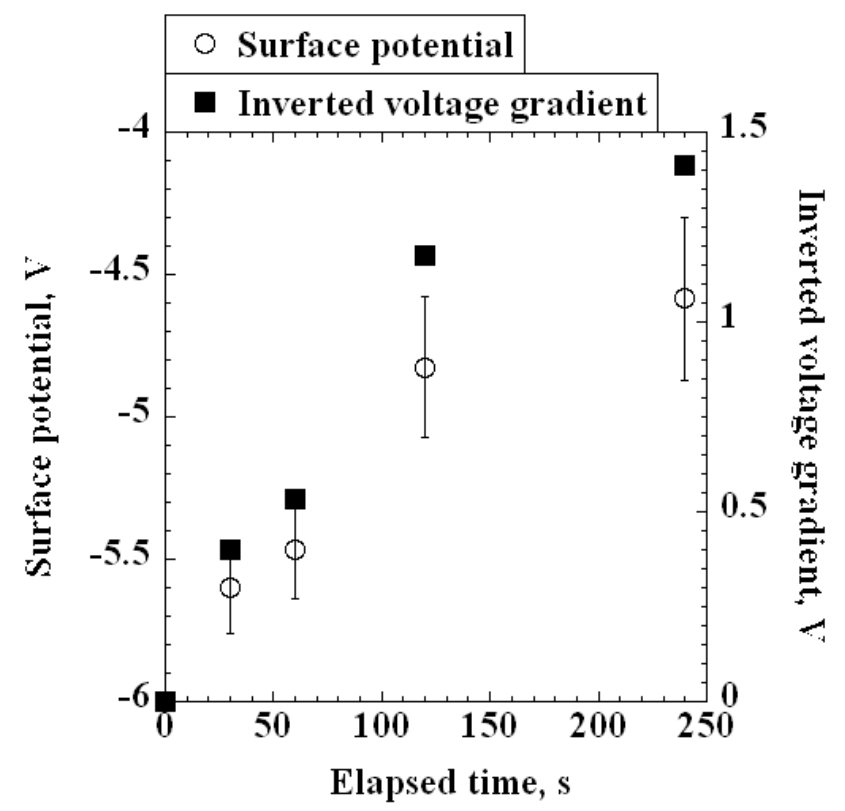

Fig. 7. Time dependence of surface potential and inverted voltage gradient.

偏差が大きいのは, Fig.6 に示したように局所的に帯電が十 分でないところがあるためである。

これまでの研究より, 電子ビーム環境下で, ブローオフ 放電が発生する乘離電圧の閾值は $400 \mathrm{~V}$ 程度と報告されて いる。Fig.7より, 本試験では 30 秒程度で, 乘離電圧は放電 発生閾值 $(400 \mathrm{~V})$ を超えていることが分かる ${ }^{(17)}$ 。乘離電圧 の大きさによって伝搬距離や伝搬速度が変化する可能性も あるが，ブローオフ放電が発生する限り，フラッシオーバ 放電も発生すると考えられる。

本試験では，表面電位分布のばらつきによる影響を可能 な限り排除するために, 可能な限り多数の放電を様々な場 所で発生させてフラッシオーバの伝搬範囲を統計的に解析 した。

太陽電池アレイ表面でフラッシオーバが発生すると, 放 電が発生した太陽電池列には正方向に電流が流れる（フラ ッシオーバ電流)。前述のとおり, フラッシオーバの電流は 太陽電池アレイ表面のカバーガラスより供給される。よっ て, 放電が発生した太陽電池列以外の太陽電池列には，負 方向の電流（中和電流）が流れる。Fig.8 に示した典型的な 


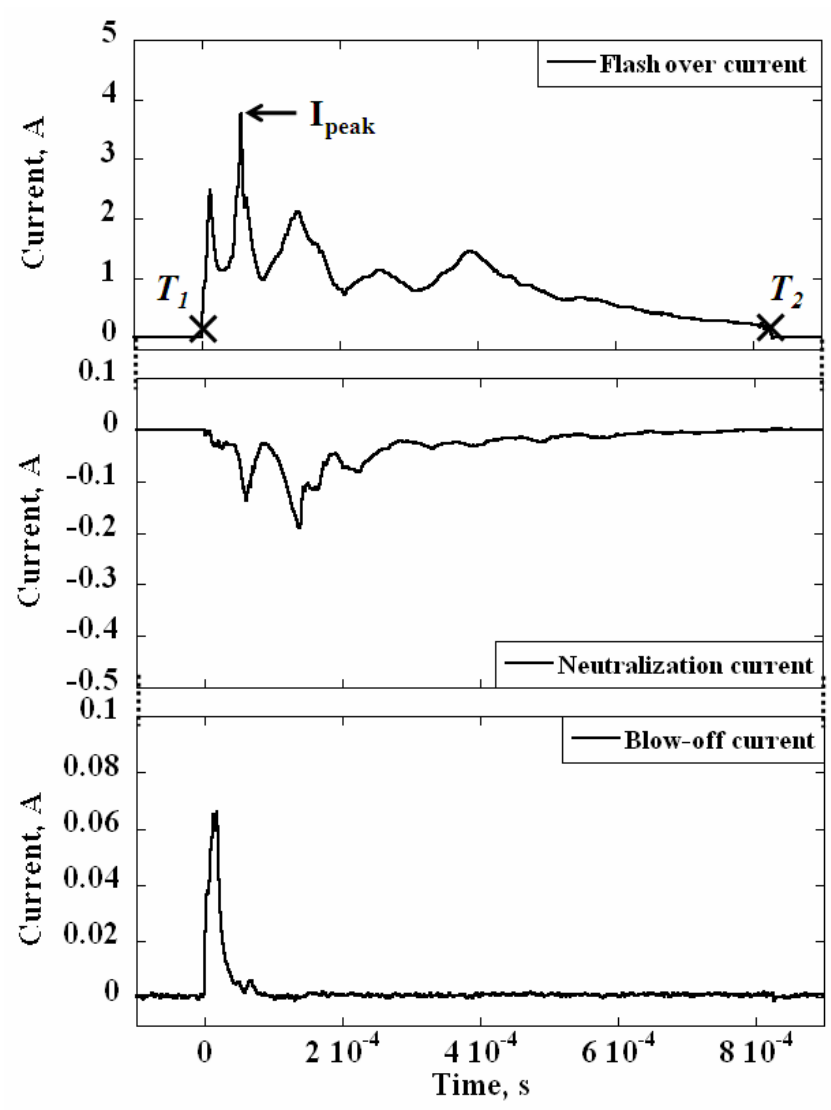

Fig. 8. Typical waveform of flashover current, neutralization current and blow-off current.

Table 1. Characteristics of flashover current and blow-off current.

\begin{tabular}{ccccc}
\hline & $\mathrm{I}_{\text {peak }}, \mathrm{A}$ & $\mathrm{T}_{\text {arc }}, \mathrm{s}$ & $\mathrm{Q}_{\text {arc }}, \mathrm{C}$ & String number \\
\hline \hline Flashover current & 3.77 & $8.10 \times 10^{-4}$ & $7.54 \times 10^{-4}$ & $\mathrm{St} 26$ \\
\hline \hline Neutralization current & -0.38 & $2.61 \times 10^{-4}$ & $-2.05 \times 10^{-5}$ & $\mathrm{St32}$ \\
\hline \hline Blow-off current & 0.06 & $5.37 \times 10^{-5}$ & $1.39 \times 10^{-6}$ & $\mathrm{St} 26$ \\
\hline \hline
\end{tabular}

フラッシオーバ電流, 中和電流, ブローオフ電流の波形よ り，電荷量やパルス幅を定義する。電流波形のピーク值を $I_{\text {peak }}$ とする。電流が $I_{\text {peak }}$ の 5 \%となった時の, 時間をそれぞ れ $\mathrm{T}_{\mathrm{i} 1}$ と $\mathrm{T}_{\mathrm{i} 2}$ とする。電流波形のパルス幅 $\mathrm{T}_{\mathrm{arc}}$ は(1) 式で定義 する。

$$
T_{a r c}=T_{i 1}-T_{i 2}
$$

また，電荷量 $\mathrm{Q}_{\mathrm{arc}}$ は(2)式で定義する。

$$
Q_{a r c}=\int_{I_{i 1}}^{T_{i 2}} i(t) d t
$$

ブローオフ電流や中和電流についても，同様な計算式を 用いて電荷量やパルス幅を計算した。Fig.8 に示した電流波 形の, 電荷量, パルス幅を Table 1 に示す。ブローオフ電流 の電荷は $\mathrm{C}_{\mathrm{ext}}(240 \mathrm{pF})$ より供給される。これに対して, フラ ッシオーバ電流の電荷はカバーガラス（一枚当たり $1 \mathrm{nF}$ 程

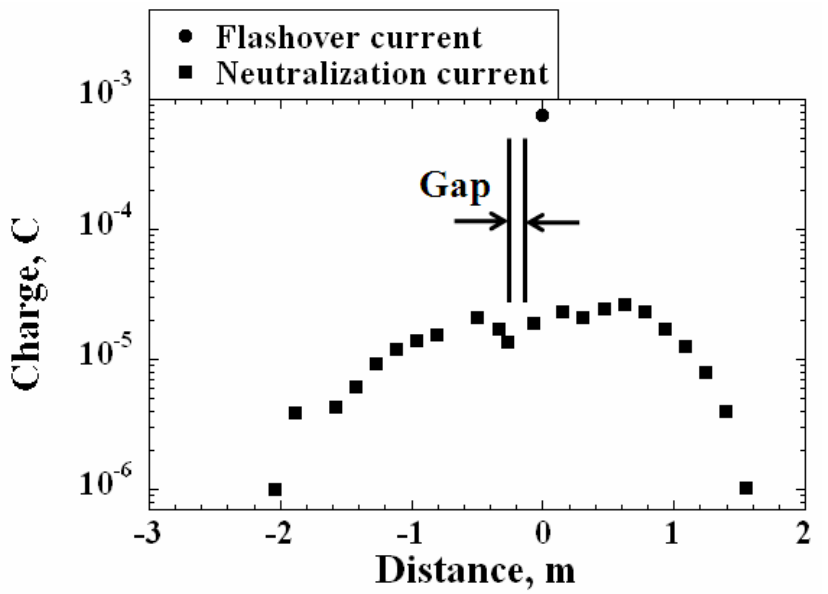

Fig. 9. Relationship between neutralization charge and distance from discharge spot.

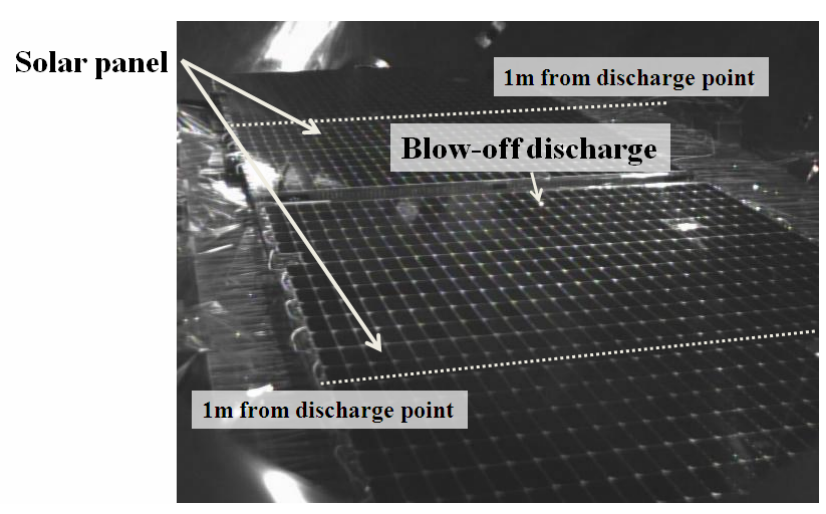

Fig. 10. Discharge illumination.

度）から供給されるので，フラッシオーバ電流の電荷量は ブローオフ電流の電荷よりも大幅に大きくなる。

Fig.8 の放電について, 全ての中和電流の電荷量を計算し た。Fig.9 にフラッシオーバ電流が発生した列からの距離と 電荷量の関係を示す。Fig.9 より, 電荷量はフラッシオーバ 電流が発生した列から離れるほど小さくなっている。これ は，フラッシオーバが発生した列から遠く離れるほどフラ ッシオーバによって発生したプラズマ（以下，プラズマと する）が中和する電荷量が少なくなることを示唆している。 Fig.10 は, Fig.8 に示した放電を観察したもので, ブローオ フ放電が真空容器内のほぼ中央で発生していることが分か る。前述の通り, クーポンパネル間には $60 \mathrm{~mm}$ 程度の空隙 が存在する。Fig.9より, 空隙の直後 $(-0.25 \mathrm{~m}$ から $-0.5 \mathrm{~m})$ では, 中和電荷量が一度低下しているものの, 他の放電で 再現性は確認できなかった。これは, 空隙の影響というよ りも, むしろ電位分布のばらつきに起因するものと考えら れる(18)。よって, 空隙の有無による伝搬範囲の変化を考慮 する必要はないと考えられる。一般的に, 伝搬範囲を測定 する場合, 放電前後の表面電位分布から求めることができ $3^{(13)(14)(16)}$ 。しかしながら, 我々は試験の効率化を図るため に, フラッシオーバ電流や中和電流の電流波形から伝搬範 囲を求めた。 


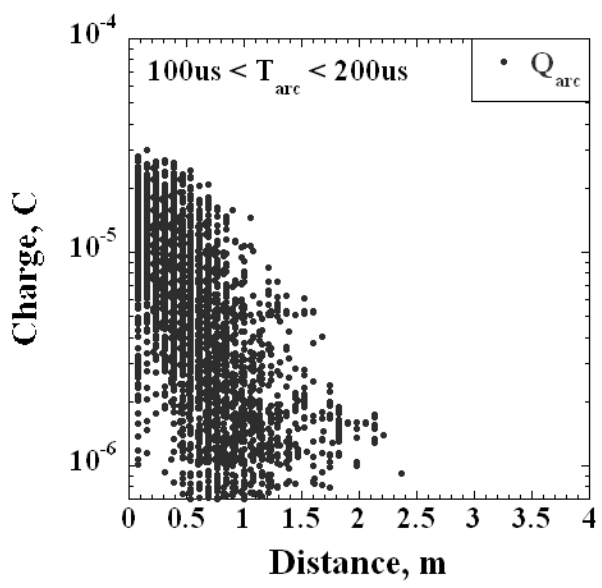

Fig. 11. Relationship between neutralization charge and distance from discharge spot $\left(100 \mu \mathrm{s}<\mathrm{T}_{\mathrm{arc}}<200 \mu \mathrm{s}\right)$.

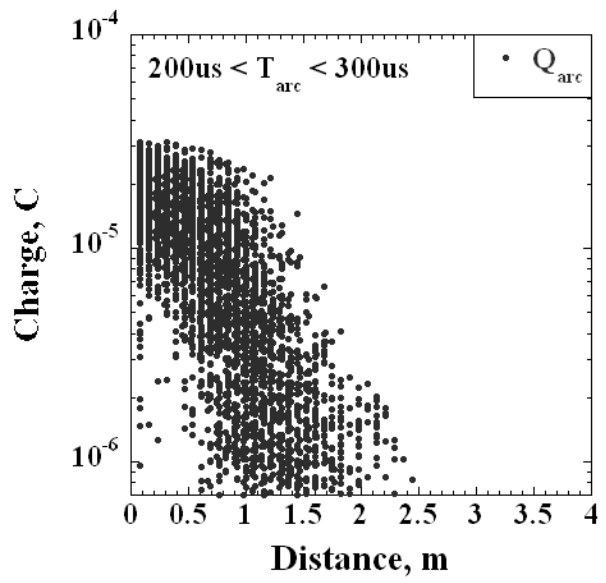

Fig. 12. Relationship between neutralization charge and distance from discharge spot $\left(200 \mu \mathrm{s}<\mathrm{T}_{\text {arc }}<300 \mu \mathrm{s}\right)$.

放電プラズマの伝搬距離を見積もる上で, フラッシオー バ電流のパルス幅は重要な指標となる。パルス幅が長くな ると，プラズマの伝搬距離もより長くなるという予測も存 在している(15)。そこで，フラッシオーバ電流のパルス幅と フラッシオーバの伝搬距離の関係について検討した。Fig.11 ～Fig.14 に，それぞれパルス幅が $100 \mu \mathrm{s} ， 200 \mu \mathrm{s} ， 300 \mu \mathrm{s}$, $400 \mu \mathrm{s}$ 以上の時の, フラッシオーバ放電が発生した列から の距離と中和電荷量の関係を示寸。Fig.11 と Fig.12より, パ ルス幅が $100 \mu \mathrm{s}$ から $200 \mu \mathrm{s}$ 台に増加したことによって，プ ラズマが蓄積されている電荷を中和する範囲が長くなって いることがわかる。しかしながら，Fig.13 と Fig.14より，パ ルス幅が $300 \mu \mathrm{s}$ 以上になっても, 電荷の中和範囲は長くな っていないことがわかる。以上のことから，フラッシオー バにより発生したプラズマは, $300 \mu \mathrm{s}$ までは進展するが, それ以上では進展しないものと考えられる。これは, ブロ 一オフ放電が発生した場所から遠く離れるほど，フラッシ オーバの抵抗值が大きくなるためと考えられる。

パルス幅が $300 \mu \mathrm{s}$ 以上の場合について，プラズマの最大

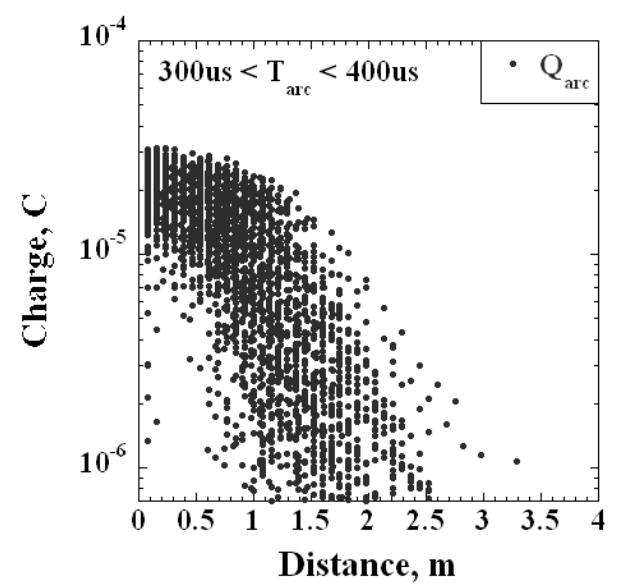

Fig. 13. Relationship between neutralization charge and distance from discharge spot $\left(300 \mu \mathrm{s}<\mathrm{T}_{\mathrm{arc}}<400 \mu \mathrm{s}\right)$.

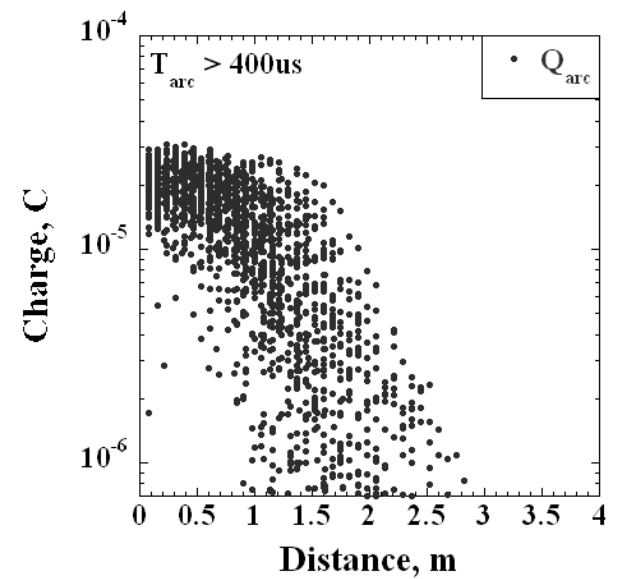

Fig. 14. Relationship between neutralization charge and distance from discharge spot $\left(\mathrm{T}_{\mathrm{arc}}<400 \mu \mathrm{s}\right)$.

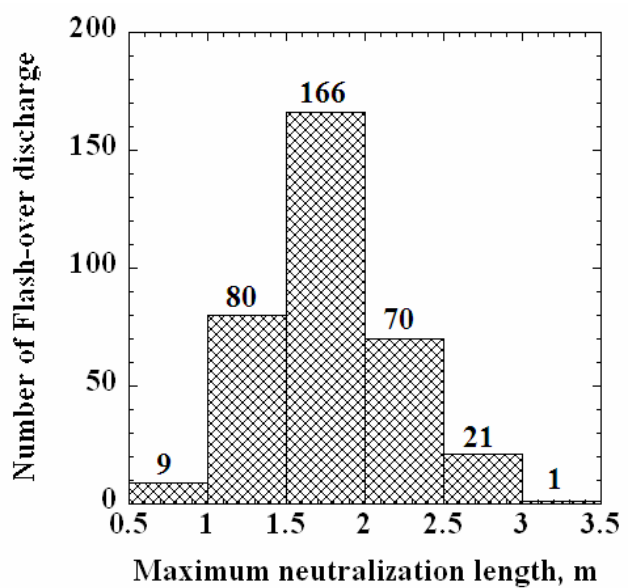

Fig. 15. Distribution of neutralization length $\left(\mathrm{T}_{\mathrm{arc}}<300 \mu \mathrm{s}\right)$.

伝搬距離を検討する。プラズマの伝搬距離を調べるために, フラッシオーバが発生した列を原点とし，中和電流が測定 された各列と原点からの距離を測定した。Fig.15 に結果を示 
す。中和電流の有無を判別するために, プログラムを使用 した。ある列に対して $(2)$ 式を適用して, 電荷量が $7 \times 10^{-7} \mathrm{C}$ 以上の場合, 中和電流が流れたと判定した。電荷量が $7 \times$ $10^{-7} \mathrm{C}$ 以下の場合は，ノイズと判別できなかったので，中和 電流は流れていないと判定した。

Fig.15 に示した最大伝搬距離と個数の関係より，166 個の 放電ではプラズマの伝搬範囲は $1.5 \mathrm{~m}$ から $2 \mathrm{~m}$ の範囲内にお さまっている。これに対して, 伝搬距離が $3 \mathrm{~m}$ を超えるよ うな放電は 1 回しか発生していない。プラズマが, ある距 離まで到達する確率を検討するために，プラズマの伝搬距 離の正規分布 $N\left(\mu, \sigma^{2}\right)$ を考える。個体数となる放電回数は 367 回である。伝搬距離の平均值 $\mu$ は $1.76 \mathrm{~m}$, 分散 $\sigma$ は 0.18 である。伝搬距離が $1.5 \mathrm{~m}$ から $2.5 \mathrm{~m}$ の範囲内となる確率は 0.92 で，伝搬距離が $2.5 \mathrm{~m}$ 以上となる確率は $2.0 \times 10^{-5}$ とな った。よって, 伝搬距離が $2.5 \mathrm{~m}$ を超えるようなフラッシオ 一バ放電は極めて発生しにくいと言うことができる。

\section{4. まとめと今後の課題}

静止軌道のプラズマ環境における太陽電池アレイ上のフ ラッシオーバ放電の伝搬距離を調べるために, 模擬静止軌 道プラズマ環境下で放電試験をおこなった。放電試験に用 いた太陽電池アレイクーポンパネルの総面積は約 $5 \mathrm{~m}^{2}$ で, 放電試験に用いられた太陽電池アレイクーポンパネルの面 積としては世界最大である。太陽電池アレイクーポンパネ ル上の太陽電池列を流れる中和電流やフラッシオーバ電流 の波形から，プラズマの伝搬範囲を調べた。

プラズマによって中和される電荷量は, 放電発生点から 遠く離れるほど小さくなることがわかった。プラズマの伝 搬範囲は, フラッシオーバ電流のパルス幅が $300 \mu \mathrm{s}$ 以下で は, フラッシオーバ電流のパルス幅の増加とともに広がる 傾向にある。しかしながら, パルス幅が $300 \mu \mathrm{s}$ 以上になる とプラズマの伝搬範囲は $3.4 \mathrm{~m}$ を上限として広がることは なかった。今回の試験から, 静止軌道のプラズマ環境にお いて, プラズマは最大でも $3.4 \mathrm{~m}$ 程度しか伝搬しないことが わかった。

ブローオフ放電の電荷は $\mathrm{C}_{\mathrm{ext}}$ から供給されるので, $\mathrm{C}_{\mathrm{ext}}$ が 大きくなると, ブローオフ放電によって発生するプラズマ の密度も変化する可能性がある。フラッシオーバの開始時 点での電荷はブローオフ放電によって発生したプラズマか ら供給される。よって $\mathrm{C}_{\mathrm{ext}}$ を変化させるとフラッシオーバの 伝搬距離も変化する可能性があるので, 今後 $\mathrm{C}_{\mathrm{ext}}$ と伝搬距離 の依存性について検討する必要がある。また, 今回の実験 では，限られた試験日程の中で可能な限りの放電データを 取得するために, 放電前後での電位の面分布を測定しなか った。今後, 中和電流から求めた伝搬距離と放電前後での 面電位分布の整合性を評価する必要がある。

\section{謝 辞}

本実験は, 宇宙航空研究開発機構宇宙科学研究本部 宇宙プラズマ研究室の協力によって実施された。本論文で 報告した実験を実施するにあたり協力していただいた AES
山本氏, 原田氏, 萩原氏, JAXA 須藤氏, 九州工業大学 鈴 木氏に感謝します。

(平成 21 年 12 月 22 日受付, 平成 22 年 6 月 7 日再受付)

\section{文献}

(1) D. Hastings and H. Garrett : Spacecraft Environment Interactions, pp. 142-198, Cambridge University Press, New York (1996)

(2) T. L. Shu and F. T. Maurice : "Aspects of Spacecraft Charging in Sunlight", IEEE Trans. Plasma Sci., Vol.34, No.5, pp.2053-2061 (2006)

(3) 真空中の放電制御技術調查専門委員会 : No.1001「高エネルギー密度 化に関わる真空中の放電制御技術」, 電気学会技術報告 (2005)

(4) M. Cho : "Status of ISO standardization efforts of solar panel ESD test methods", 10th Spacecraft Charging Technology Conference on Disk [CD-ROM], Biarritz, France (2007)

(5) T. Okumura, H. Masui, K. Toyoda, M. Imaizumi, and M. Cho : "Degradation of electric performance due to electrostatic discharge on silicon solar cell for space", J. Jpn Soc. Aeronautical \& Space Sci., Vol.55, No.647, pp.590-596 (2007)

(6) V. Inguimbert, D. Sarrail, J-C. Mateo-Velez, R. Reulet, L. Levy, F. Boulay, and D. Payan : "Electrostatic Discharge and Secondary Arcing on Solar Array - Flashover Effect on Arc Occurrence", IEEE Trans. Plasma Sci., Vol.36, No.5, pp.2404-2412 (2008)

( 7 ) K. Toyoda, K. Masui, T. Muranaka, M. Cho, T. Urabe, T. Miura, S. Kawakita, Y. Gonohe, and T. Kikuchi : "ESD Ground Test of Solar Array Coupons for a Greenhouse Gases Observing Satellite in PEO", IEEE Trans. Plasma Sci., Vol.36, No.5, pp.2413-2424 (2008)

( 8 ) K. Toyoda, T. Matsumoto, Y. Shikata, M. Cho, T. Sato, and Y. Nozaki : "ESD Ground Test of Solar Array Coupons for a Wideband Internetworking Satellite", J. Jpn Soc. Aeronautical \& Space Sci., Vol.52, No.606, pp.328-336 (2004)

(9) K. Toyoda, T. Matsumoto, M. Cho, Y. Nozaki, and M. Takahashi : "Power Reduction of Solar Arrays due to Arcing Under Simulated GEO Environment", J. Spacecraft \& Rockets, Vol.41, No.5, pp.854-861 (2004)

(10) T. Okumura, K. Masui, K. Toyoda, M. Cho, K. Nitta, and M. Imaizumi : "Environmental Effects on Solar Array Electrostatic Discharge Current Waveforms and Test Results", J. Spacecraft \& Rockets, Vol.46, No.3, pp.697-705 (2009)

(11) M. Cho : "Status of ISO standardization efforts of solar panel ESD test methods", 10th Spacecraft Charging Technology Conference, Biarritz, France (2007)

(12) P. Leung and M. Bodeau : "Plasma Phenomena Associated with Solar Array Discharges and Their Role in Scaling Coupon Test Results to a Full Panel", 8th Spacecraft Charging Technology Conference, Huntsville, USA (2003)

(13) H. Masui, K. Toyoda, and M. Cho : "Electrostatic Discharge Plasma Propagation Velocity on Solar Panel in Simulated Geosynchronous Environment", IEEE Trans. Plasma Sci., Vol.36, No.5, pp.2387-2394 (2008)

(14) M. Amorim and D. Payan : "Electrostatic Discharges on a 1M2 Solar Array Coupon - Influence of the Energy Stored on Coverglass on Flashover Current", 9th Spacecraft Charging Technology Conference, Tsukuba, Japan (2005)

(15) B. Vayner, D. Ferguson, and J. Galofaro : "The Effect of Solar Array Size on Sustained Arc Inception", 47th AIAA Aerospace Science Meeting, AIAA 2009-115, Orlando, Florida, USA (2009)

(16) T. Kawasaki, S. Hosoda, J. Kim, K. Toyoda, and M. Cho : "Charge Neutralization via Arcing on Large Solar Array in the GEO Plasma Environment", IEEE Trans. Plasma Sci., Vol.34, No.5, pp.1979-1985 (2006)

(17) M. Cho, R. Ramasamy, T. Matsumoto, K. Toyoda, Y. Nozaki, and M. Takahashi : "Laboratory Tests on 110V Solar Arrays in a Simulated Geosynchronous Orbit Environment", 2003, J. Spacecraft \& Rocket, Vol.40, No2, pp.211-220 (2003)

(18) 原田次郎・萩原洋介・奥村哲平 - 仁田工美・高橋眞人 - 豊田和弘: 「模 擬静止軌道環境における大型太陽電池パネルの電荷収集測定」, 平成 21 年度スペースプラズマ研究会, 相模原市 (2010) 
奥 村 哲 平 (非会員) 2007 年 12 月九州工業大学大学院博 士課程修了。現在, 宇宙航空研究開発機構研究開発本部電源グルー プ宇宙航空プロジェクト研究員。衛星帯電に関する研究, 及び化合 物太陽電池の品質評価に関する研究に従事。アメリカ航空宇宙学会 会員。

仁田工 美 （正員）1989 年 3 月日本女子大学卒業。電機义 一カ一勤務の後, 2005 年東京大学大学院工学系研究科博士課程修 了。現在, 宇宙航空研究開発機構研究開発本部電源グループ主任開 発員。工学博士。宇宙機の帯電・放電現象の研究及びスペースデブ リに関するに従事。応用物理学会会員。
高 橋 眞 人 (非会員) 1982 年 3 月詫間電波工業高等専門学 校卒業。同年旧宇宙開発事業団（現，宇宙航空研究開発機構）に入 社。現在, 研究開発本部電源グループ技術領域リーダー。宇宙機の 電源系の研究開発に従事。

豊 田 和 弘 (正員) 2001 年 3 月東京大学大学院博士課程修 了。現在, 九州工業大学宇宙環境技術研究センターにて, 衛星帯電 に関する研究に従事。アメリカ航空宇宙学会会員。 